\title{
In vitro and in vivo, antibacterial effect of lactobacillus and ethanolic extract of sage Salvia officinalis on enteropathogenic E.coli (EPEC)
}

$$
\begin{aligned}
& \text { التأثير المضاد للعصيات اللبنية والمستخلص الكحولي لنبات الميرميا على بكتريا } \\
& \text { الممرضة داخل وخارج الجسم الحي enteropathogenic E.coli (EPEC) }
\end{aligned}
$$

Amina N. AlThawani

Rasha abdul-Hussein Mahood

$$
\begin{aligned}
& \text { Institute of Genetic Engineering and Bio-Technology/ Baghdad University } \\
& \text { *Biotechnology Research Center/ AL-Nahrain University }
\end{aligned}
$$

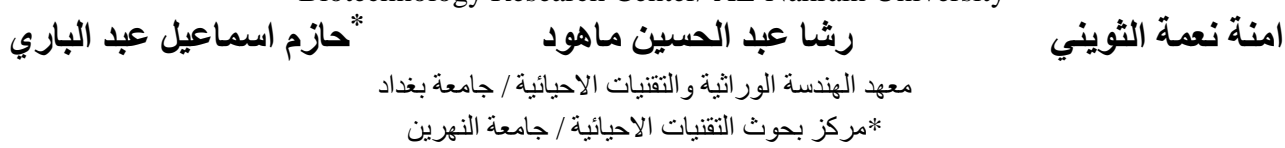

Abstract

The antibacterial effect of Lactobacillus cell-free filtrate and ethanolic extract of sage Salvia officinalis on enteropathogenic E.coli (EPEC) were investigated in vitro and in vivo. In vitro, antibacterial activity of Lactobacillus and ethanolic extract of sage were determined by using well diffusion method. The results of ethanolic extract of sage showed moderate antibacterial activity even with high concentration of extract $20 \mathrm{mg} / \mathrm{ml}$ with maximum inhibition zone $18 \mathrm{~mm}$. while, of Lactobacillus cell-free filtrate presented high antibacterial activity against E.coli (24mm) in vivo, thirty two albino male mice(age 8-10 weeks, weight ranged 2327 gram) were used in this experiment. The animals were divided into four equal groups, include positive and negative controls. Histological analysis of intestine, liver and kidney showed that the mice infected with EPEC induce attaching and effacing (A/E) lesions and loss of microvillus actins rootlets as well as microvillus fragmentation and no significant changes in liver and kidney tissues of mice infected with EPEC. Normal microvilli and mucosal morphology observed in mice infected and treated with Lactobacillus and ethanolic extract of sage.

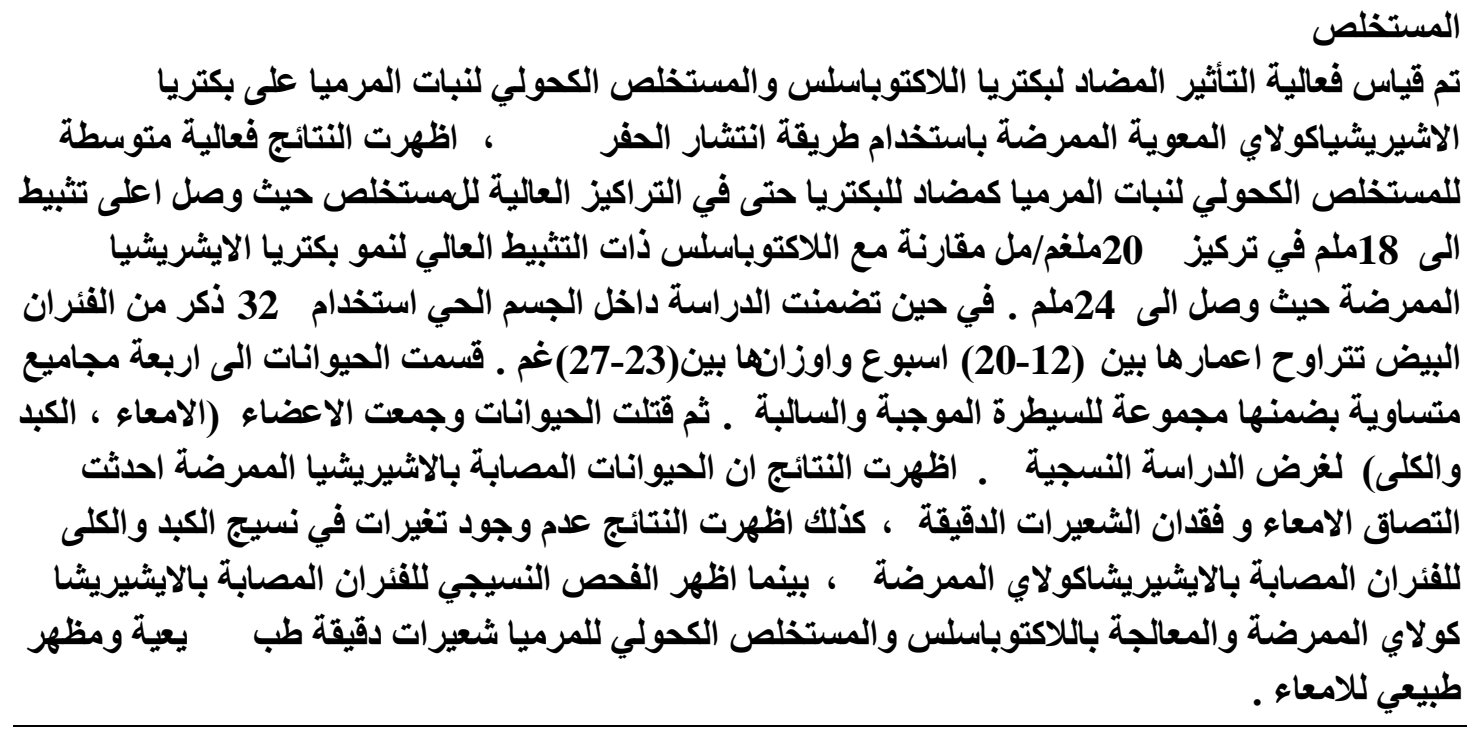




\section{Introduction}

Enteropathogenic E.coli (EPEC) is a human enteric pathogen that attaches to the surface of intestinal epithelial cells and causes watery diarrhea. The first stage of EPEC attachment to the human host is called localized adherence, where EPEC forms dense microcolonies on the surface of intestinal epithelial cells [1]. This initial attachment of EPEC to host cells occurs through a plasmid-encoded bundle-forming pilus (BFP) [2]. After initial adherence, EPEC induces localized effacement of microvilli and intimately attaches to the host cell surface, forming characteristic attaching and effacing (A/E) lesions [3].

Resident microflora of the gastrointestinal tract plays an important role in inhibiting gut colonization by incoming pathogens [4]. Different mechanisms enable this normal flora to play such a role [5]: first, some strains or species can prevent pathogen adherence by specifically competing for the same receptor sites, or alternatively by providing an aspecific steric hindrance as a barrier to mucosal colonization; second, the production of antimicrobial metabolites (bacteriocinlike or nonbacteriocin substances) by the normal flora can remove pathogens from the intestine; and third, some strains can exhibit an enhancement of the host immune response against pathogens. Recently, the idea has emerged to select among lactic acid bacterial strains those which are able to be incorporated into the resident flora and to demonstrate beneficial potentialities, then to investigate their biological effects both in vitro and in vivo, and finally use them in dairy products offering health benefits [6]. One of these "probiotic" bacterial strains, Lactobacillus johnsonii La1 (formerly Lactobacillus acidophilus La1), has shown immunomodulatory properties on the one hand [7], and antipathogenic properties on the other hand, both in vitro and in vivo [8]. The other properties can be based either on the strain ability to adhere to the gastrointestinal tract [9], or on the secretion of an antimicrobial components active in vitro and in vivo [8].

Sage, Salvia officinalis L. (Lamiaceae) is an aromatic perennial plant native to southern Europe and Asia Minor. It is cultivated as a culinary herb and as a plant of great medicinal importance, officially listed in pharmacopoeias of many countries throughout the world. Leaf extracts of this plant have antibacterial effects [10], antiviral [11], anti-inflammatory, antihydrotic [12] and antioxidant properties [13] . The aim of this work is to Study the antimicrobial activity and histopathological effect of Lactobacillus and ethanolic extract of sage (Salvia officinalis L.) on EPEC in vitro and in vivo.

\section{Materials and Methods}

\section{Plant Sage (Salvia officinalis L.)}

\section{Plant Collection and Identification}

The plant was collected from local market in May 2010 and identified by prof. Dr.Ali AL - Mosawy, Biology Department, College of Science, Baghdad University. Preparation of Plant Extracts

The leaves of sage were air-dried at room temperature $(20-25)^{\circ} \mathrm{C}$, and then powdered by coffee grinder. Fifty grams of the leaf powder were extracted for three hours in 250 $\mathrm{ml}$ ethanol using $45^{\circ} \mathrm{C}$ water bath in soxhlet apparatus. Then leaf extract solution was 
evaporated at $45^{\circ} \mathrm{C}$ using a rotary evaporator, and the resultant crude extract was frozen at $-20^{\circ} \mathrm{C}$ until use to prepare the required doses and concentrations [14].

\section{Sage Doses and Concentrations}

This dose, the alcoholic extract was dissolved in phosphate buffer solution PBS.

\section{Experimental Design}

The experiments were designed to evaluate (in vivo and in vitro) effects of sage extracts and lactobacillus on albino male mice treated with EPEC.

(in vitro)Determination inhibitory effect of Lactobacillus on EPEC

MRS broth was inoculated with $1 \%$ of Lactobacillus isolates then incubated at 37C for 18 hours. After incubation, the culture was centrifuged at $6000 \mathrm{rpm}$ for $15 \mathrm{~min}$, and filterd through millipor filter unit $(0.22 \mu \mathrm{m})$. According to well diffusion method that mentioned by [16]. Sabourad agar plate was inoculated with $0.1 \mathrm{ml}$ of enteropathogenic E.coli by a spreader then; $5 \mathrm{~mm}$ well was made by the cork borer. The well was filled with Lactobacillus supernatant, and then incubated at 37C FOR $24 \mathrm{hr}$. Incubation zone around the well were measured by $(\mathrm{mm})$ and compared with that of control which contained MRS broth only.

\section{(In vivo) Laboratory Animals}

Thirty two mice were obtained from Biotechnology Research Center at Al-nahrain University. Their age among (8-10)weeks and weighting (23-27)gm. They were divided into four equal groups as following:- Negative control (the animals given phosphate buffer solution PBS), positive control (the animals of this group administrated orally by $1.5 \times 10^{8} \mathrm{cfu} / \mathrm{ml}$ EPEC), mice with third group orally administrated with same dose $\left(1.5 \times 10^{8}\right)$ of EPEC and Lactobacillus, while the fourth group mice administrated orally $\left(1.5 \times 10^{8}\right)$ of EPEC and treated with ethanol extract of sage. Laboratory animals was sacrificed after (7) days.

\section{Histological Examinations}

Histological examination was diagnosed under supervision of the histopathologist. The samples which was fixed in (10\%) formalin solution was washed by tap water for few minutes and left in ethanol $50 \%$ for 30min while $70 \%$ ethanol was used to keep the samples for a long time. The samples was transferred to $(2.5 \%$ absolute ethanol, $75 \%$ butanol) then left for ( $2 \mathrm{hr}$ ). Paraffin wax sectioned in $(4 \mu \mathrm{m})$ thickness to be easier to use, then samples was stained with hematoxyline - eosin stain as desecribed by Guyer [17].

\section{Results and discussion}

In vitro

Antibacterial activity of lactobacillus (cell free filtrate) and ethanol extract of sage on EPEC

Well diffusion method was used to determine the inhibition activity of Lactobacillus and ethanolic extract of sage on EPEC .High inhibitory effect was obtained during using supernatant of Lactobacillus, the inhibition zone reached to $24 \mathrm{~mm}$, while the results showed moderate inhibition activity of ethanol extract of sage with maximum inhibition zone $(18 \mathrm{~mm})$. 
Table (1): Antibacterial activity of Lactobacillus (cell free filtrate) and ethanol extract of sage on Enteropathogenic E.coli EPEC

$\begin{gathered}\text { Pathogenic } \\ \text { bacteria }\end{gathered}$
Inhibition zone diameter $(\mathbf{m m})$

Ethanolic extract of sage

E.coli

$\begin{array}{cccccc}2.5 & 5 & 10 & 20 & 40 & 80 \\ \text { mg/ml } & \mathrm{mg} / \mathrm{ml} & \mathrm{mg} / \mathrm{ml} & \mathrm{mg} / \mathrm{ml} & \mathrm{mg} / \mathrm{ml} & \mathrm{mg} / \mathrm{ml} \\ \text { N.I. } & 10 & 12 & 15 & 17 & 18\end{array}$

Lactobacillus streptomycin (cell_free (positive filtrate) control)

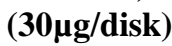

\section{N.I.: no inhibition zone}

Such finding was confirmed by [18] who mention that MRS broth stimulated inhibitory effect against Gram positive and Gram negative bacteria, similar results were also obtained by [19] who found that best inhibitory effect was gained when liquid media (MRS broth) was used to estimate the effect of Lactobacillus on pathogenic bacteria. In recent years, the use of Lactobacilus as biotherapeutic agents has received wider attention and several studies provide evidence supporting the ability of Lactobacilli to prevent infection [20] although many commercially available Lactobacillus products can be found in healthy food stores, their reliability is questionable and there is only little evidence proving their efficacy [21].

Many studies demonstrated that the essential oils of sage exhibited remarkable bacteriostatic and bactericidal activities against Bacillus cereus, Bacillus megatherium, Klebsiella oxytoca, Staphylococcus aureus [22]. Other studies showed that the antibacterial activity of the acetone extract of Salvia spp. inhibited the growth of Bacillus cereus, Streptococcus pyrogens, Escherichia coli bacteria tested at minimum inhibitory concentration (MIC) of $0.5 \mathrm{mg} / \mathrm{ml}$ [23].

\section{In vivo}

\section{Histological examination in mice infected with EPEC}

Histological changes were detected in different organs (intestine, liver, kidney) in mice administrated with EPEC. Intestine section shows localized effacement of microvilli in intestinal epithelial cells, forming characteristic attaching and effacing $\mathrm{A} / \mathrm{E}$ lesions Figure (1 A and B), While the negative control shows normal intestinal epithelium Figure (2). Liver and kidney sections shows normal appearance as illustrated in Figure $(3,4)$.

A

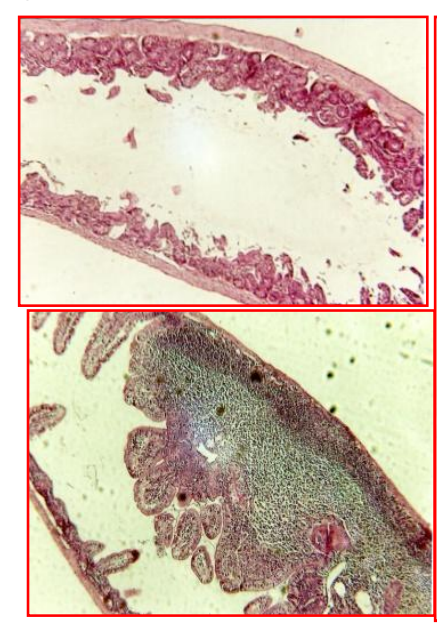

Figure (1): A,B:cross section in mice intestine infected with EPEC show localized effacement of microvilli(hematoxyline-eosin stain 10x)

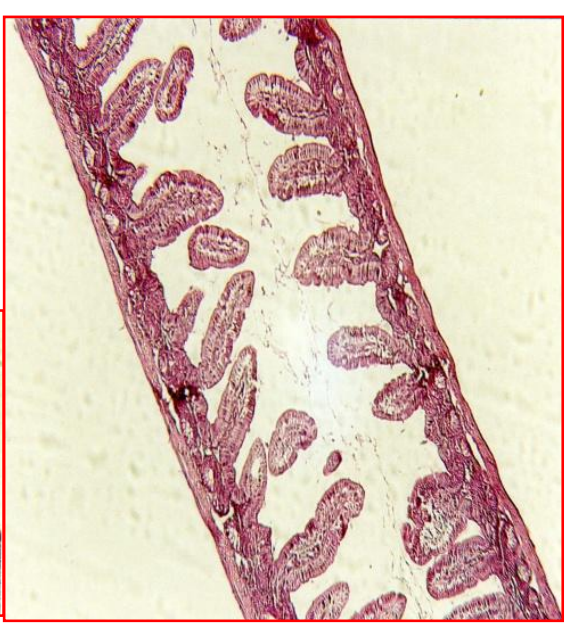

Figure (2): Cross section in mice intestine(control group) show normal microvilli (hematoxyline-eosin stain 10x) 


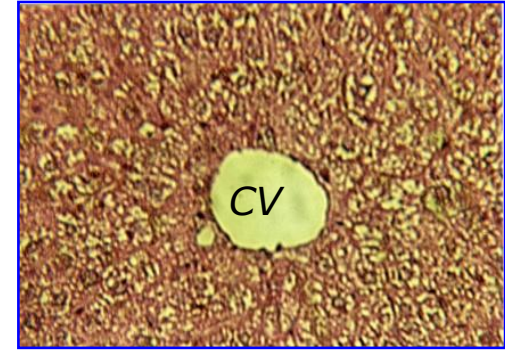

Figure (3): Cross section in liver of mice infected with EPEC show normal morphology and central vein (cv) (hematoxyline-eosin stain 40x)

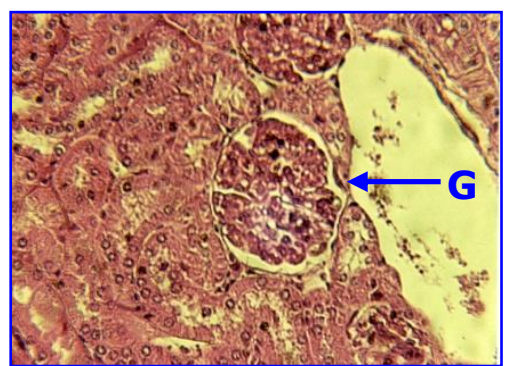

Figure (4): Cross section in kidney of mice infected with EPEC show normal morphology and glomerular (G) (hematoxyline-eosin stain 10x)

Histological changes in mice intestine infected with EPEC and treated with Lactobacillus (cell free filtrate) and ethanol extract of sage

The intestinal epithelium of treated mice showed normal microvilli and normal mucosal morphology Figure $(5,6)$.

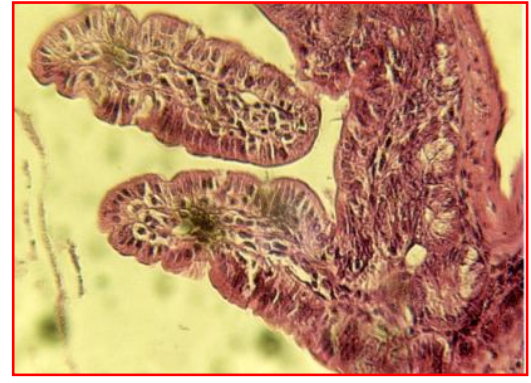

Figure (5): Cross section in mice intestine infected with EPEC and treated with ethanolic extract of sage show normal microvilli and normal mucosal morphology(hematoxyline-eosin stain 40x)

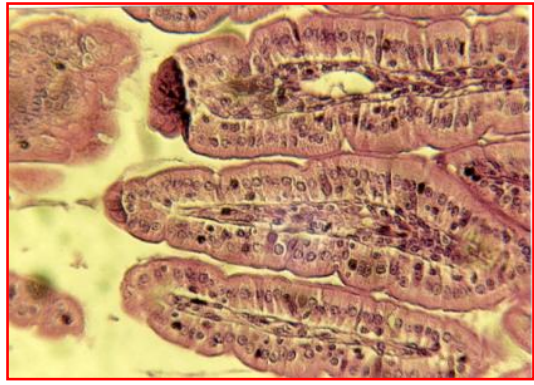

Figure (6): Cross section in mice intestine infected with EPEC and treated with lactobacillus show normal microvilli and normal mucosal morphology(hematoxylineeosin stain 40x)

The adhesion of lactobacilli to receptors on surface epithelial cells could compete for binding sites with enteric pathogens. It is also possible that lactic acid-producing bacteria reduce both the viability and the virulence properties of E. coli O157:H7 [24] and other diarrheagenic E. coli [25]. Several previous reports indicated that factors other than lactic acid produced by probiotics, including bacteriocins, proteinases, peroxides, and exopolysaccharides, could exert antibacterial effects [26]. Even though there are many factors responsible for causing diarrhea (including osmotic imbalance, indigestion of dairy products) entericinfection is the leading cause of diarrhea in developing countries. EPEC lack fimbriae, ST and LT toxins, but they utilize an adhesion known as intimin to bind to host intestinal cells [27].This virotype has an array of virulence factors that are similar to those found in Shigella.Adherence to the intestinal mucosa causes are arrangement of actin in the host cell, leading to significant deformation [28]. EPEC cells are moderately-invasive and elicit an inflammatory response. Changes in intestinal cells ultra structure due to attachment and effacement are likely to be the prime cause of diarrhea in those afflicated with EPEC [29].The adherence of EPEC principally involves binding of the pathogen to intestinal mucosa with the help of the $90 \mathrm{KD}^{\mathrm{a}}$ outer membrane protein , intimin [29]. 


\section{References}

1. Moon H. W., Whipp S. C., Argenzio R. A., Levine M. M., and Giannella R. A. (2006). Attaching and effacing activities of rabbit and human enteropathogenic Escherichia coli in pig and rabbit intestines. Infect. Immun. 41:1340-1351.

2. Frankel G., Phillips A., Rosenshine I., Dougan G., Kaper J. B., and Knutton S. (2001). Enteropathogenic and enterohaemorrhagic Escherichia coli: more subversive elements. Mol. Microbiol. 30:911-921.

3. Vallance B. A. and Finlay B. B. (2000). Exploitation of host cells by enteropathogenic Escherichia coli. Proc. Natl. Acad. Sci. USA 97:8799-8806

4. Berg R.D. (1996). The indigenous gastrointestinal microflora. Trends Microbiol., 4:430-435.

5. Finlay B.B. and Siebers A. (2000). Mechanisms of mucosal colonization and penetration by bacterial pathogens. In Roth, J.A., Bolin, C.A., Brogden, K.A., Minion, F.C. and Wannemuhler, M.O. (eds.), Virulence Mechanisms of Bacterial Pathogens, 2nd ed. American Society for Microbiology, Washington, DC. pp. 33-45.

6. Brassart D. and Schiffrin, E.J. (2008). Probiotics for improved gut health. Trends Food Sci. Technol. 8: 321-326

7. Haller D., Blum, S., Bode Ch., Hammes W.P. and Schiffrin E.J. (2000). Activation of human PBMC by non-pathogenic bacteria in vitro: evidence of NK cells as primary targets. Infect. Immun. 68: 752-759

8. Bernet-Camard,M-F., Liévin V., Brassar D., Neese J.-R., Servin A.L. and Hudault,S. (2002) .The human Lactobacillus acidophilus strain Lal secretes a non bacteriocin antibacterial substance active in vitro and in vivo. Appl. Environ. Microbiol. 63: 2747-2753.

9. Bernet, M-F., Brassart D., Neeser J.-R. and Servin A.L. (1994). Lactobacillus acidophilus LA 1 binds to cultured human intestinal cell lines and inhibits cell attachment and cell invasion by enterovirulent bacteria. Gut. 35: 483-489.

10. Farag R.S., DawZ.Y. HewediF.M.,ELbaroty G.S.(2005). Antimicrobial activity of some egyption spice oils .J.Food protection. 52:665-667.

11. 11.Tada M.,Okuno K., Chiba K.,Ohnishi E., Yoshii T.(2000). Antiviral diterpenes from salvia officinalis .phytochemistry. 35:539-541.

12. Leung A.Y. (1999).Cosmetics made from Chinese herb extracts. Drug and cosmetics industry. April:35_40.

13. Miura K., Kikuzaki H., Nakatani N. (2002). Antioxidant activity of chemical components from sage and thyme measured by the oil stability index method. J. Agric. Food chem. 50:1845.

14. Nadir, M. T.; Salih, F. M.; Dhahir, A. J.; Nori, M. and Hussain, A. M. (1986) Antimicrobial activity of Salvia species indigenous to Iraqi. J. Bio. S. R. 17: 109-117.

15. Farahat, G. N.; Affra, N. I. and Gali-Muhtasib, H. A. (2001). Seasonal changes in the composion of the essential oil extract of East Mediterranean sage (Salvia libanotica) and it's toxicity in mice. Toxicon. 39: 1601-1605.

16. Lewus,C.B.;Kaiser,A.and Montville,T.j.(1991).Inhibition of food-borne bacterial pathogens by bacteriocins form lactic acid bacteria isolated from meat. J. Appl. Environ Microbial. 57:1683-1688. 
17. Guyer M. (1993). Animal microbiology $5^{\text {th }}$ Ed. The University of Chicago press. Chicago.

18. Tadao, S. (2004). Selection of useful probiotic lactic acid bacteria from the lactobacillus acidophilus group and their applications to functional foods.Animal ScienceJ. 75:1-13.

19. Kubba, M. A. (2006). Improvement of inhibition effect of probiotic against some bacterial isolate using prebiotic. M.Sc thesis. Al-Nahrain University.

20. Sullivan, A. and Nord, C. (2002). Probiotics in human infections. Journal of Antimicrobial Chemotherapy. 50:625-627.

21. Rastall, R. and Maitin, V. (2002). Prebiotics and synbiotics: towards the next generation. Curr. Opin. Biotechnol.13:490-496.

22. Anapaulu, L.; Moschen,T.,Liano A., Luciana M., and E. Sergio (2007). Antibacterial activity of the essential oils of salvia officinalis L. and Salvia Triloba L. cultivated in south brazil. Food chemistry.100(2): 603-608.

23. Delamare, A., Sampson J., Theobald A. and Har S. (2007). Antibacterial activity of essential oils of Salvia officinalis L. and Salvia triloba L. cultivated in South Brazil. Food Chemistry. 100(2): 603-608.

24. Radulescu, V.; Okello E., Perry N. and Wilkins R. (2004). Capillary gas chromatography-mass spectrometry of volatile and semi-volatile compounds of Salvia officinalis. Journal of Chromatography A. 1027(1-2): 121-126.

25. Avato, P., Kennedy D., Perry E.and Ballard C. (2005). Glandular hairs and essential oils in micropropagated plants of Salvia officinalis L. Plant Science. 169(1): 29-36.

26. Brashears, M. M., S. S. Reilly, and Gilliland S. E (1998). Antagonistic action of cells of Lactobacillus lactis toward Escherichia coli O157:H7 on refrigerated raw chicken meat. J. Food Prot. 61:166-170.

27. Gansheroff, L.J., M.R. Wachtel, A.D. O'Brien. (1999). Decreased adherence of enterohemorrhagic Escherichia coli to HEp-2 cells in the presence of antibodies that recognize the C-terminal region of intimin. Infect Immunol. 67: 6409-6417.

28. Gouin, E., M.D. Welch and P. Cossart. (2005). Actin-based motility of intracellular pathogens. Curr. Opin. Microbiol. 8: 35-45.

29. Arbeloa, A., R.R. Bulgin, G. MacKenzie, R.K. Shaw and M.J Pallen et al. 2008. Subversion of actin dynamics by EspM effectors of attaching and effacing bacterial pathogens. Cell Microbiol. 10: 1429-1441. 